JURNAL PENDIDIKAN, p-ISSN 2715-095X, e-ISSN 2686-5041

Volume 29, No.2, Juli 2020 (159-168)

Online: http://journal.univetbantara.ac.id/index.php/ip

\title{
Penerapan Metode Inkuiri untuk Meningkatkan Kreativitas Siswa dalam Menggambar Ragam Hias
}

\author{
Achmadi \\ UPTD SMP Negeri 2 Mojolaban, Email: utomoachmadi @gmail.com
}

\begin{abstract}
Abstrak: Tujuan penelitian ini adalah untuk meningkatkankreativitas siswa dalam Menggambar Ragam Hias melalui metode inkuiri pada siswa kelas VII C UPTD SMP Negeri 2 Mojolaban Sukoharjo semester 1 tahun pelajaran 2019/2020. Penelitian ini merupakan Penelitian Tindakan Kelas (PTK). Penelitian dilakukan dalam dua siklus, tiap siklus terdiri atas perencanaan, pelaksanaan tindakan, observasi, dan refleksi. Subjek penelitian adalah siswa kelas VIIC SMP Negeri 2 Mojolaban yang berjumlah 32 siswa. Penelitian ini dilakukan pada bulan Juli sampai bulan September 2019. Teknik pengumpulan data adalah dengan observasi, wawancara, dan dokumentasi. Teknik analisis data menggunakan teknik analisis deskriptif komparatif dan teknik analisis kritis.Hasil penelitian menunjukkan bahwa melalui penerapan metode inkuiri dapat meningkatkan kreativitas siswa dalam menggambar ragam hias siswa kelas VIIC UPTD SMP Negeri 2 Mojolaban Sukoharjo. Pada siklus I saat diterapkan metode inkuiri persentasekreativitas meningkat menjadi $61,5 \%$, dengan indikator ketercapaian 59\% karya siswa adanya pengembangan bentuk dan 64\% karya siswa dengan komposisi baik, kemudian pada siklus II meningkat hingga $88 \%$ dengan indikator ketercapaian $86 \%$ karya siswa adanya pengembangan bentuk dan $90 \%$ karya siswa dengan komposisi baik.
\end{abstract}

Kata-Kata Kunci : kreativitas, menggambar ragam hias, inkuiri

\section{Application Inquire Method To Improve Student Creativity In Drawing of Ornament}

\author{
Achmadi \\ UPTD SMP Negeri 2 Mojolaban,Email: utomoachmadi@gmail.com
}

\begin{abstract}
The purpose of this research is to improve student creativity in drawing many kinds of decoration at the seventh-C grade students of UPTD SMP Negeri 2 Mojolaban Sukoharjo in 2019/2020 academic year by applying inquire method.This research is classroom action research. This research has done in 2 (two) cycles, each cycles consist of planning, action implementation, observation and reflection. The subject of this research is seventh-C grade students of UPTD SMP Negeri 2 Mojolaban which consist of 32 (thirty two) students. This research has done in July until September 2094. The technique of data collecting which has done in this research are observation, interview, and documentation. The technique of data analysis which has used are comparative descriptive technique and critical analysis technique.The result of this research showed that by applying inquire method can improve student creativity in drawing of ornament at seventh-C grade students of UPTD SMP Negeri 2 Mojolaban Sukoharjo. In the first cycle when inquire method applied, percentage value of students creativity increase to $61,5 \%$ with reaching indicators of student work $59 \%$ there is developing shape, and good composition of student work $64 \%$. Then in the second cycle increase up to $88 \%$ with increasing indicators of student work $86 \%$ there is developing shape and good composition of student work $90 \%$.
\end{abstract}


Keywords : Creativity, drawing of ornament, inquiry.

\section{Pendahuluan}

Sejalan dengan diterapkannya Kurikulum 2013 (K-13) maka perlu adanya sistem inovasi pembaharuan metode atau model pembelajaran yang lebih mendorong siswa bergairah belajar, sehingga kelak menghasilkan lulusan yang kompetitif, berbudi luhur, peduli dengan lingkungan, budaya, dan kegiatan dimasyarakat. Pendidikan seni sebagai bagian dari Pendidikan Nasional seyogyanya memperhatikan makna yang terkandung di dalam tujuan Nasional, yaitu berperan dalam mengembangkan kehidupan individu dalam pengembangan kepribadiannya baik dalam aspek kecerdasan, perasaan dan kehendak. UPTD SMP Negeri 2 Mojolaban Sukoharjo adalah sebuah Sekolah Menengah Pertama yang mempunyai jumlah siswa cukup besar, dari kelas VII sampai dengan kelas IX jumlah peserta didiknya 958 siswa, yang terdiri dari 30 rombel, yaitu 10 ruang kelas VII, 10 ruang kelas VIII, dan 10 ruang kelas IX. Dari sejumlah siswa yang cukup banyak tersebut terdapat kompleksitas permasalahan. Dalam pelaksanaan proses pembelajaran seni rupa pada UPTD SMP Negeri 2 Mojolaban khususnya kelas VII C menunjukkan sebagian besar hasil karya dalam menggambar ragam hias nilainya masih sangat rendah dan kurang kreatif. Ragam hias disebut juga ornamen, merupakan salah satu bentuk karya seni rupa yang sudah berkembang sejak zaman prasejarah (Kementerian Pendidikan dan Kebudayaan, 2013).

Metode yang digunakan guru dalam proses pembelajaran masih menggunakan teknik pembelajaran konvensional yaitu dengan metode ceramah, tanya jawab, demonstrasi, dan penugasan, sehingga siswa merasa jenuh dan tidak aktif.Peneliti adalah salah satu guru seni budaya khususnya seni rupa di UPTD SMP Negeri 2 Mojolaban.Pada saat mengajar peneliti mendapatkan beberapa siswa yang kurang siap atau takut gambarnya jelek, malas, dan kurang gairah serta kurang kreatif. Rendahnya hasil kreativitas siswa pada materi menggambar ragam hias yaitu 39,50\% hal ini dikarenakan kurangnya kreatifitas siswa dalam menggambar. Guru dengan berbagai cara telah mengusahakan agar semua siswa aktif dalam kegiatan belajar mengajar. Hal ini juga ditunjukkan dari hasil karya siswa yang nilainya masih sangat rendah yaitu 67,9 . Hasil karya siswa yang nilainya sudah memenuhi KKM (Kriteria Ketuntasan Minimal) baru 75\%, sehingga masih ada 25\% dari jumlah siswa yang belum memenuhi KKM (Kriteria Ketuntasan Minimal). Berdasarkan pengamatan langsung yang dilakukan peneliti dengan melihat hasil karya siswa, masih ada beberapa siswa yang kurang kreatif dalam menggambar ragam hias.Hal ini dapat dilihat dari beberapa hasil karya siswa yang masih mencontoh gambar yang sudah ada dan tidak mengembangkan bentuk yang dicontoh. Siswa masih belum bisa menyusun komposisi gambar. Banyak bidang yang dibiarkan kosong yang seharusnya dapat diisi dengan ornamen lain. Semakin banyak ornamen yang disusun berdasarkan prinsip-prinsip seni rupa, akan dihasilkan gambar ragam hias yang menarik. Karya-karya yang dihasilkan siswa belum menunjukkan bentuk-bentuk yang baru, dan dari masing-masing karya siswa mempunyai bentuk yang hampir sama (mendekati sama) dengan yang dicontohkan guru. Siswa belum bisa menggunakan daya imajinasinya dalam menggambar ragam hias. Kurangnya kreativitas dan rendahnya nilai hasil karya siswa dalam menggambar ragam hias juga disebabkan karena guru kurang melaksanakan variasi pembelajaran, siswa merasa kesulitan, jenuh, beranggapan bahwa pelajaran seni rupa sebagai pelajaran yang tidak penting, sehingga jika diberi tugas tidak pernah selesai dan siswa cenderung tidak 
aktif dalam mengikuti pembelajaran. Dari hasil observasi dan wawancara yang telah dilakukan dengan siswa dan melihat nilai hasil karya siswa, maka faktor utama yang dirasakan sebagai penyebab kurangnya kreativitas siswa dalam menggambar ragam hias adalah karena pembelajaran yang dilakukan dengan metode yang digunakan oleh guru seperti yang telah dikemukakan di atas kurang menarik dan kurang merangsang siswa untuk kreatif, sehingga berpengaruh terhadap hasil karya siswa.

Kemampuan yang dimiliki seseorang untuk mengembangkan potensi dirinya dalam menciptakan sesuatu yang baru disebut kreativitas.Kreativitas siswa yang kurang dalam pembelajaran menggambar ragam hias dapat menjadi suatu permasalahan yang segera diatasi dengan melakukan tindakan.Tindakan yang dilakukan adalah dengan melakukan penelitian tindakan kelas. Untuk meningkatkan kreativitas dan mengurangi kejenuhan siswa dalam menggambar ragam hias maka guru dalam pembelajaran menggambar ragam hias harus mencari variasi model pembelajaran yang menarik dan menyenangkan, yang melibatkan siswa.Disamping itu guru harus memilih metode pembelajaran yang sesuai dengan kondisi siswa. Metode pembelajaran adalah cara yang digunakan guru untuk menyampaikan pelajaran kepada siswa (Hamdani, 2010). Karena penyampaian itu berlangsung dalam interaksi edukatif, metode pembelajaran dapat diartikan sebagai cara yang dipergunakan oleh guru dalam mengadakan hubungan dengan siswa pada saat berlangsungnya pengajaran.

Dengan demikian, metode pembelajaran merupakan alat untuk menciptakan proses belajar mengajar. Metode pembelajaran menekankan proses belajar siswa secara aktif dalam upaya memperoleh peningkatan hasil belajar. Guru seharusnya memikirkan cara (metode) yang membuat siswa dapat belajar secara optimal. Dalam arti sesuai dengan tingkat kemampuan masing-masing. Untuk meningkatkan kualitas proses pembelajaran seperti itu maa perlu penekanan kepada aktivitas siswa secara maksimal untuk mencari dan menemukan. Metode yang cocok dalam hal ini adalah metode inkuiri. Metode inkuiri adalah teknik pengajaran guru dengan membagi tugas kepada siswa untuk meneliti suatu masalah.Metode inkuiri termasuk salah satu metode yang inovatif.Dengan menggunakan metode inkuiri dapat merangsang dan mendorong siswa untuk lebih berfikir kreatif.Gulo (2002) menyatakan strategi inkuiri berarti suatu rangkaian kegiatan belajar yang melibatkan secara maksimal seluruh kemampuan siswa untuk mencari dan menyelidiki secara sistematis, kritis, logis, analitis, sehingga mereka dapat merumuskan sendiri penemuannya dengan penuh percaya diri (Trianto, 2007).

Dalam pembelajaran dengan metode inkuiri siswa belajar secara aktif dan guru berfungsi sebagai motivator.Siswa dalam mengamati sesuatu, mengumpulkan data, mendiskusikan masalah, menyimpulkan hipotesa dilakukan secara kelompok.Dengan keterlibatan siswa secara aktif dalam kelompok, siswa dapat mengembangkan potensipotensi yang dimiliki. Pembelajaran inkuiri merupakan satu komponen penting dalam pendekatan konstruktivistik yang telah memiliki sejarah panjang dalam inovasi atau pembaruan pendidikan.Dalam pembelajaran dengan penemuan/inkuiri, siswa didorong untuk belajar sebagian besar melalui keterlibatan aktif mereka sendiri dengan konsepkonsep dan prinsip-prinsip, dan guru mendorong siswa untuk memiliki pengalaman dan 
melakukan percobaan yang memungkinkan mereka menemukan prinsip-prinsip diri mereka sendiri (Nurhadi, Burhan Yasin dan Agus Gerrad Senduk, 2004). Berdasarkan uraian di atas, maka dapat dirumuskan masalah: "Apakah dengan menerapkan metode inkuiridapat meningkatkan kreativitas siswa dalam Menggambar Ragam Hias pada siswa kelas VII C UPTD SMP Negeri 2 Mojolaban Sukoharjo semester 1 tahun pelajaran 2019/2020?”.

\section{Metode Penelitian}

Penelitian ini adalah Penelitian Tindakan Kelas.Tujuan Penelitian Tindakan Kelas (PTK) menurut Suwandi (2011) adalah "Untuk mengadakan perbaikan atau peningkatan mutu praktik pembelajaran di kelas" (hlm. 16). Dengan melaksanakan Penelitian Tindakan Kelas (PTK) guru dapat memperbaiki pembelajarannya, mengembangkan ketrampilannya dan memungkinkan secara aktif mengembangkan pengetahuannya serta menumbuhkan budaya meneliti pada lingkungan guru.Penelitian ini dilaksanakan di UPTD SMP Negeri 2 Mojolaban.Tahaptahap pelaksanaan kegiatan dilakukan selama kurang lebih lima bulan yaitu sejak bulan Juli sampai dengan November 2019. Peneliti sebagai guru UPTD SMP Negeri 2 Mojolabanbertindak sebagai subjek yang melakukan tindakan kelas.Teman sejawat sesama guru mata pelajaran Seni Budaya sebagai observer.Kepala Sekolah bertindak sebagai subjek yang membantu dalam perencanaan dan pengumpulan data. Subjek yang menerima tindakan adalah siswa kelas VII CUPTD SMP Negeri 2 Mojolaban semester I tahun pelajaran 2019/2020 sebanyak 32 siswa.Adapun prosedur/langkah-langkah dalam pelaksanaan penelitian tindakan kelas ini diwujudkan dalam bentuk siklus. Menurut Arikunto (2014) bahwa “ bagan penelitian tindakan kelas secara garis besar terdapat empat tahapan yang lazim dilalui, yaitu (1) perencanaa, (2) pelaksaan, (3) pengamatan, dan (4) refleksi.

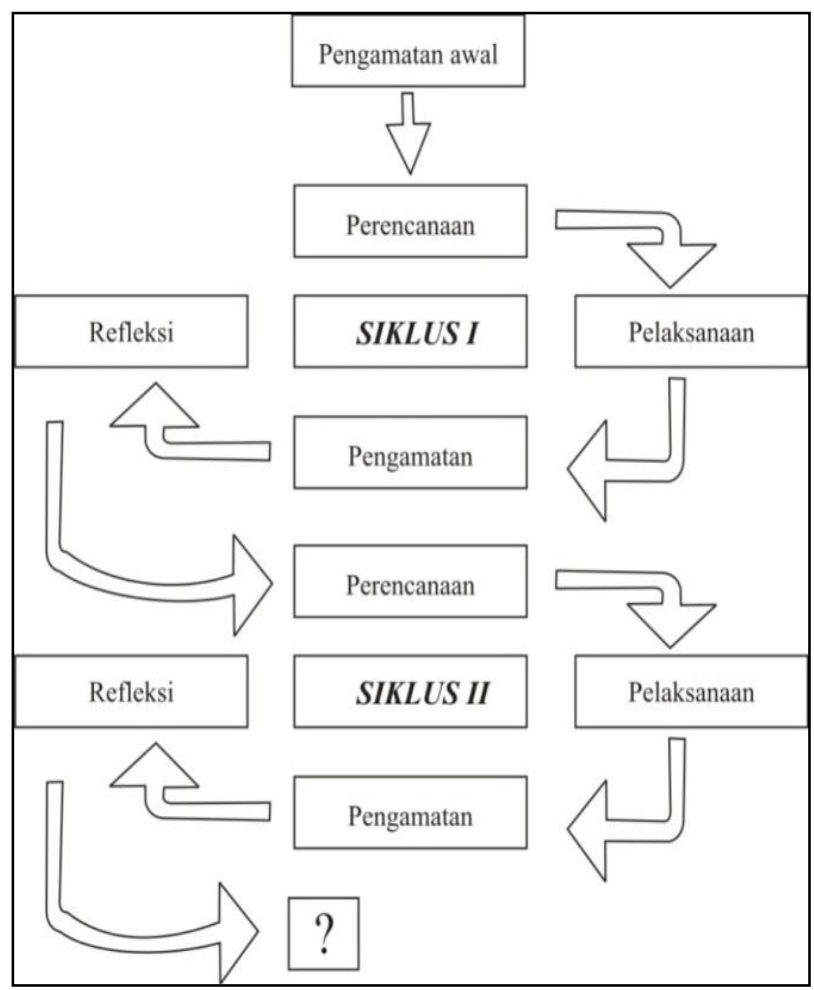




\section{Gambar 1. Tahapan PTK}

Suyadi (2012) berpendapat bahwa "dalam penelitian tindakan kelas minimal terdiri dari dua siklus". Pada penelitian ini terdiri dari dua siklus yang mencakup empat kegiatan yaitu perencanaan, pelaksanaan, pengamatan dan refleksi.Cara-cara memperoleh data dalam kegiatan penelitian dikenal sebagai metode pengumpulan data. Ada beberapa macam metode pengumpulan, diantaranya meliputi: metode observasi, tes, dokumentasi, dan wawancara. Dalam penelitian tindakan kelas ini metode pengumpulan data yang digunakan adalah: metode observasi, metode wawancara, dan metode dokumentasi.Observasi sering disebut pula pengamatan. Pengamatan atau observasi dalam penelitian, dapat dilakukan dengan tes, kuesioner, rekaman gambar dan rekaman suara (PPPG tertulis, 2004: 8). Metode Observasi (pengamatan) ini digunakan untuk mengamati secara langsung tentang prilaku siswa maupun guru, yang dilakukan sebelum tindakan maupun pada waktu pelaksanaan tindakan selama proses pembelajaran. Dalam penelitian ini wawancara dilakukan antara peneliti dan teman guru mata pelajaran seni budaya dan antara peneliti dengan siswa. Wawancara dengan teman guru dilakukan di luar pembelajaran, dan dilaksanakan setelah melakukan pengamatan pertama terhadap kegiatan belajar mengajar, dengan tujuan untuk memperoleh informasi tentang kesulitan yang dihadapi oleh guru pada saat melakukan pembelajaran menggambar ragam hias, kreativitas siswa dalam menggambar ragam hias, dan untuk mengetahui sejauh mana kelebihan dari metode yang digunakan. Wawancara dengan siswa dilaksanakan diluar pembelajaran, dimaksud untuk memperoleh informasi tentang kesulitan dalam menggambar ragam hias.Wawancara dilaksanakan dengan menanyakan tentang kesulitan yang dihadapi oleh siswa dalam menggambar ragam hias sebelum menggunakan metode inkuiridan setelah menggunakan metode inkuiri dalam pembelajaran. Metode dokumentasi digunakan untuk memperoleh data penelitian yang bersumber pada tulisan berupa dokumen. Pelaksanaan metode dokumentasi, peneliti menyelidiki benda-benda tertulis misalnya: buku-buku, dokumen kegiatan, peraturan-peraturan dan sebagainya (PPPG tertulis, 2004: 9).Dokumen yang diteliti sebagai sumber data dalam penelitian ini meliputi: 1) dokumen yang berbentuk tulisan, seperti silabus, RPP dan nilai siswa. 2) dokumen yang berbentuk gambar, yaitu gambar ragam hias siswa. Metode inkuiri dapat meningkatkan kreativitas siswa dalam menggambar ragam hias pada klas VII C SMP Negeri 2 Mojolaban dengan indikator keberhasilan tindakan seperti yang dirumuskan pada tabel dibawah.Indikator keberhasilan kinerja dalam penelitian ini adalah meningkatkan kemampuan untuk mengembangkan bentuk yaitu $80 \%$ yang diamati dengan cara membandingkan bentuk pengembangan dengan bentuk yang dijadikan sumber ide. Kemampuan siswa membuat komposisi dengan baik $80 \%$ yang diukur melalui hasil karya siswa dengan berdasarkan prinsip-prinsip seni rupa.

\section{Hasil Penelitian}

Adapun identifikasi masalah meliputi : 1) masalah guru, guru dalam mengajar masih menggunakan metode konvensional, yaitu dengan ceramah, tanya jawab, dan demonstrasi. 2) masalah siswa, dalam pembelajaran beberapa siswa ngobrol sendiri, tidak mendengarkan penjelasan guru, karena merasa bosan, hasil gambar siswa masih kurang 
dari KKM, karena kreativitas siswa kurang. 3) masalah prasarana, media pembelajaran yang digunakan oleh guru masih sangat sederhana, yaitu menggunakan contoh gambar hasil karya siswa tahun yang lalu dan pemberian contoh gambar di papan tulis dengan demonstrasi guru.

Tabel 1.Data Hasil Pengamatan Kreativitas Siswa Kondisi Awal

\begin{tabular}{clc}
\hline No & Indikator/ Aspek yang diamati & Kondisi Awal \\
\hline 1 & Pengembangan bentuk & $40 \%$ \\
\hline 2 & Komposisi & $39 \%$ \\
\hline \multicolumn{2}{c}{ Rata-rata (Kreativitas) } & $39,5 \%$
\end{tabular}

Pada tabel 1.data pengamatan mengenai kreativitas siswa dalam menggambar ragam hias ternyata masih kurang. Persentasekreativitas siswa rata-rata mencapai 39,5\%, dengan perincian pengembangan bentuk mencapai $40 \%$ dan penyusunan komposisi mencapai 39\%. Berikut ini persentaseketuntasan nilai praktek (ketrampilan) menggambar ragam hias siswa kelas VIIC pada kondisi awal.

Tabel 2.Data Nilai Praktek (Ketrampilan) Siswa Kondisi Awal

\begin{tabular}{cccc}
\hline \multirow{2}{*}{ No } & \multirow{2}{*}{ Ketuntasan } & \multicolumn{2}{c}{ Kondisi Awal } \\
\cline { 3 - 4 } & & Jumlah Siswa & $\%$ \\
\hline 1 & Tuntas & 13 & $40,62 \%$ \\
\hline 2 & Tidak tuntas & 19 & $59,37 \%$ \\
\hline \multicolumn{3}{c}{ Rata - rata } & \multicolumn{3}{c}{67,87} \\
\hline
\end{tabular}

Dari tabel 2 tersebut dapat kita ketahui bahwa rata-rata nilai praktek (ketrampilan) sebesar 67,87\%. Siswa yang telah tuntas sebanyak 13 siswa (40,62\%). Dari hasil ini terlihat masih banyak siswa yang belum tuntas, yaitu 19 siswa (59,37\%) dari 32 siswa di kelas VII C. Untuk lebih jelasnya nilai praktek (ketrampilan) siswa dalam menggambar ragam hias dapat dilihat pada grafik dibawah ini. Berdasarkan identifikasi masalahan di atas, maka perlu adanya tindakan yang mengarah pada perbaikan. Adapun tindakan yang diperlukan adalah: metode yang digunakan guru dalam pembelajaran dipilih metode yang sesuai, yang tidak membosankan, sehingga dapat merangsang kreativitas siswa dalam menggambar ragam hias. Adapun metode yang dipilih adalah metode inkuiri. Metode inkuiri tersebut dalam penerapannya siswa dibagikan gambar dari beberapa bentuk daun dan bunga, dan juga siswa diajak mengamati (melihat langsung) bentuk daun dan bunga pada tanaman sekitar. Pengamatan/observasi dilakukan oleh peneliti bersama observer pada waktu pelaksanaan tindakan siklus I.

Adapun hasil pengamatan ketika tindakan siklus I dilaksanakan antara lain; 1) tingkat pemahaman siswa tentang menggambar ragam hias, sebagian besar siswa sudah mengetahui pengertian dari ragam hias, bagian-bagian ragam hias, unsur-unsur seni rupa dan prinsip-prinsip seni rupa. 2) Kemampuan siswa dalam menemukan ide, dari gambar yang diberikan guru dapat meningkatkan pemahaman tentang ragam hias dan dengan melihat obyek secara langsung di lingkungan sekolah dapat ditemukan ide yang bisa dikembangkan menjadi bentuk ragam hias. 3) Kemampuan siswa mengembangkan bentuk, dalam membuat ornamen utama, bentuk yang dibuat masih ada yang belum dikembangkan/digayakan menjadi bentuk baru. 4) Kemampuan menyusun komposisi dalam menggambar ragam hias, dalam pengolahan unsur-unsur seni rupa, kemampuan siswa terbatas pada sebagian dari beberapa prinsip-prinsip seni rupa.

Tabel 3.Data Hasil Pengamatan Kreativitas Siswa Siklus I 


\begin{tabular}{clc}
\hline No & Indikator/ Aspek yang diamati & Siklus I \\
\hline 1 & Pengembangan bentuk & $59 \%$ \\
\hline 2 & Komposisi & $64 \%$ \\
\hline & Rata-rata (Kreativitas) & $61,5 \%$
\end{tabular}

Pada tabel 3 data pengamatan mengenai kreativitas siswa dalam menggambar ragam hias ternyata sudah ada peningkatan.Persentasekreativitas siswa rata-rata mencapai $61,5 \%$, dengan perincian pengembangan bentuk mencapai $59 \%$ dan penyusunan komposisi mencapai $64 \%$. Berikut ini persentaseketuntasan nilai praktik gambar ragam hias siswa kelas VIIC pada Siklus I.

Tabel 4.Data Nilai Praktek (Ketrampilan) Siswa Siklus I

\begin{tabular}{cccc}
\hline \multirow{2}{*}{ No } & \multirow{2}{*}{ Ketuntasan } & \multicolumn{3}{c}{ Siklus I } \\
\cline { 3 - 4 } & & Jumlah Siswa & $\%$ \\
\hline 1 & Tuntas & 23 & $72 \%$ \\
\hline 2 & Tidak tuntas & 9 & $28 \%$ \\
\hline \multicolumn{3}{c}{ Rata - rata } & \multicolumn{3}{c}{75,75} \\
\hline
\end{tabular}

Dari tabel 4. tersebut dapat kita ketahui bahwa rata-rata nilai praktek (ketrampilan) sebesar $75,75 \%$. Siswa yang telah tuntas sebanyak 23 siswa (72\%). Dari hasil ini terlihat masih banyak siswa yang belum tuntas, yaitu 9 siswa (28\%) dari 32 siswa di kelas VII C. Untuk lebih jelasnya nilai praktek (ketrampilan) siswa dalam menggambar ragam hias dapat dilihat pada grafik dibawah ini.

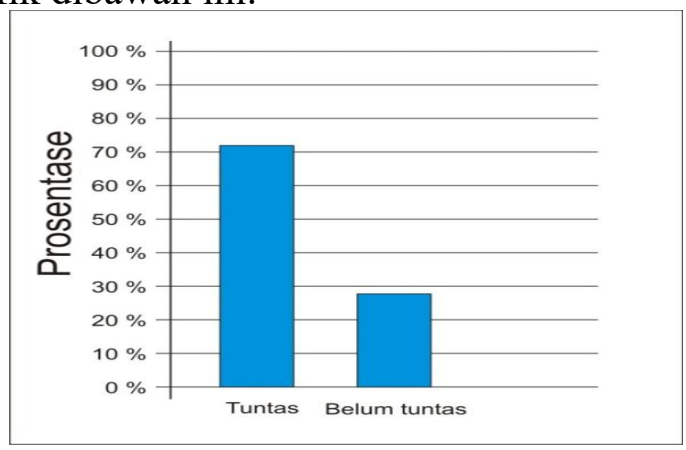

Gambar 5.Ketuntasan Nilai Ketrampilan Menggambar Ragam Hias Siklus I

Dari pengamatan di atas, secara garis besar hasil karya menggambar ragam hias kelas VII C UPTD SMP Negeri 2 Mojolaban Sukoharjo, sudah menunjukkan peningkatan.Berdasarkan hasil pengamatan pada siklus I diketahui bahwa, gambar ragam hias yang dihasilkan siswa sudah cukup kreatif, dimana siswa sudah dapat mengembangkan bentuk dan menyusun komposisi dengan baik, dan dalam mengembangkan unsur-unsur seni rupa sudah cukup variatif, akan tetapi indikator keberhasilan yang ditentukan belum terpenuhi. Indikator keberhasilan yang dicapai adalah $61,5 \%$ karya siswa adanya pengembangan bentuk dan 59\% karya siswa dengan komposisi baik, pada hal indikator keberhasilan yang dirumuskan adalah $80 \%$ karya siswa adanya pengembangan bentuk dan $80 \%$ karya siswa dengan komposisi baik. Sehingga untuk pelaksanaan tindakan pada siklus 
II perlu perbaikan dalam hal-hal tertentu. Pengamatan/observasi dilakukan oleh peneliti bersama observer ketika pelaksanaan tindakan siklus II.

Adapun hasil dari pengamatan ketika tindakan siklus II dilaksanakan antara lain ; 1) tingkat pemahaman siswa tentang menggambar ragam hias; hampir semua siswa sudah mengetahui tentang pengertian ragam hias, bagian-bagian ragam hias dan cara menggambar ragam hias yang meliputi bagaimana membuat ornamen utama, ornamen tambahan dan isen. 2) kemampuan siswa mengembangkan bentuk; sebagian besar siswa sudah dapat menyetilir/menggayakan bentuk daun/bunga dari bentuk aslinya. 3) kemampuan menyusun komposisi dalam menggambar ragam hias; penyusunan komposisi dalam menggambar ragam hias yang dibuat oleh siswa sudah banyak variasi dan bentuknya menarik, ada karya siswa yang komposisinya terpusat, diagonal, repetisi, keseimbangan simetris, keseimbangan asimetris dan gradasi. Berikut ini hasil pengamatan kreativitas gambar ragam hias siswa klas VII C pada siklus II.

Tabel 5. Data Hasil Pengamatan Kreativitas Siswa Siklus II

\begin{tabular}{clc}
\hline No & Indikator/ Aspek yang diamati & Siklus II \\
\hline 1 & Pengembangan bentuk & $86 \%$ \\
\hline 2 & Komposisi & $90 \%$ \\
\hline & Rata-rata (Kreativitas) & $88 \%$
\end{tabular}

Pada tabel 5.data pengamatan mengenai kreativitas siswa dalam menggambar ragam hias menunjukkan peningkatan yang sangat tajam. Persentasekreativitas siswa rata-rata mencapai $88 \%$, dengan perincian pengembangan bentuk mencapai $90 \%$ dan kemampuan penyusunan komposisi mencapai $86 \%$. Berikut ini persentaseketuntasan nilai praktik (ketrampilan) menggambar ragam hias siswa kelas VII C pada Siklus II.

Tabel 6. Data Nilai Praktik (Ketrampilan) Siswa Siklus II

\begin{tabular}{cccc}
\hline \multirow{2}{*}{ No } & \multirow{2}{*}{ Ketuntasan } & \multicolumn{2}{c}{ Siklus II } \\
\cline { 3 - 4 } & & Jumlah Siswa & $\%$ \\
\hline 1 & Tuntas & 30 & $93,75 \%$ \\
\hline 2 & Tidak tuntas & 2 & $6,25 \%$ \\
\hline \multicolumn{3}{c}{ Rata - rata } & \multicolumn{3}{c}{83.75} \\
\hline
\end{tabular}

Dari tabel 6.tersebut dapat kita ketahui bahwa rata-rata nilai praktek (ketrampilan) sebesar $83,75 \%$. Siswa yang telah tuntas sebanyak 30 siswa $(93,75 \%)$. Dari hasil ini terlihat berkurangnya siswa yang belum tuntas, yaitu 2 siswa $(6,25 \%)$ dari 32 siswa di kelas VII C.

\section{Pembahasan}

Berdasarkan pengamatan pada siklus II, dapat diperoleh kesimpulan : 1) contoh gambar yang digunakan sebagai sumber ide dapat meningkatkan daya imajinasi siswa. 2) dengan pengamatan tanaman sekitar siswa mampu menumbuhkan daya imajinasi dan kreativitas siswa. 3) secara garis besar ketrampilan menggambar ragam hias yang dihasilkan siswa kelas VII C UPTD SMP Negeri 2 Mojolaban, Sukoharjo sudah menunjukkan peningkatan yang tinggi dari siklus I. Hasil siklus II secara keseluruhan adalah sebagai berikut; 1) kreativitas siswa dalam menggambar ragam hias meningkat.Hal tersebut dapat dilihat dari hasil karya siswa yang sudah banyak pengembangan bentuk dan dengan komposisi yang baik. Kreativitas siswa pada siklus II ini tercapai $86 \%$ karya siswa 
adanya pengembangan bentuk dan 90\% karya siswa dengan komposisi baik. 2) jumlah siswa yang tuntas meningkat dari 23 siswa menjadi 30 siswa. 3) berdasakan nilai karya siswa satu kelas, maka rata-rata nilai kelas meningkat dari 75,8 menjadi 83,8. Dari uraian diatas terlihat bahwa penerapan metode inkuiri dalam menggambar ragam hias dapat meningkatkan kreativitas siswa. Indikator keberhasilan penelitian yang dirumuskan peneliti yaitu $80 \%$ karya siswa adanya pengembangan bentuk dan $80 \%$ karya siswa dengan komposisi baik telah tercapai. Oleh karena itu tidak perlu dilakukan tindakan selanjutnya.

Tabel 7. Peningkatan Kreativitas Siswa dalam Menggambar Ragam Hias

\begin{tabular}{llcccc}
\hline No & $\begin{array}{c}\text { Indikator/ Aspek yang } \\
\text { diamati }\end{array}$ & $\begin{array}{c}\text { Kondisi } \\
\text { Awal }\end{array}$ & Siklus I & Siklus II & Peningkatan \\
\hline 1 & Pengembangan bentuk & $40 \%$ & $59 \%$ & $86 \%$ & $46 \%$ \\
\hline 2 & Komposisi & $39 \%$ & $64 \%$ & $90 \%$ & $51 \%$ \\
\hline & Rata-rata (Kreativitas) & $39,5 \%$ & $61,5 \%$ & $88 \%$ & $48,5 \%$ \\
\hline
\end{tabular}

Berdasarkan hasil pengamatan kreativitas siswa dalam menggambar ragam hias dari kondisi awal sampai dengan siklus II, dapat diperjelas dengan grafik dibawah ini.

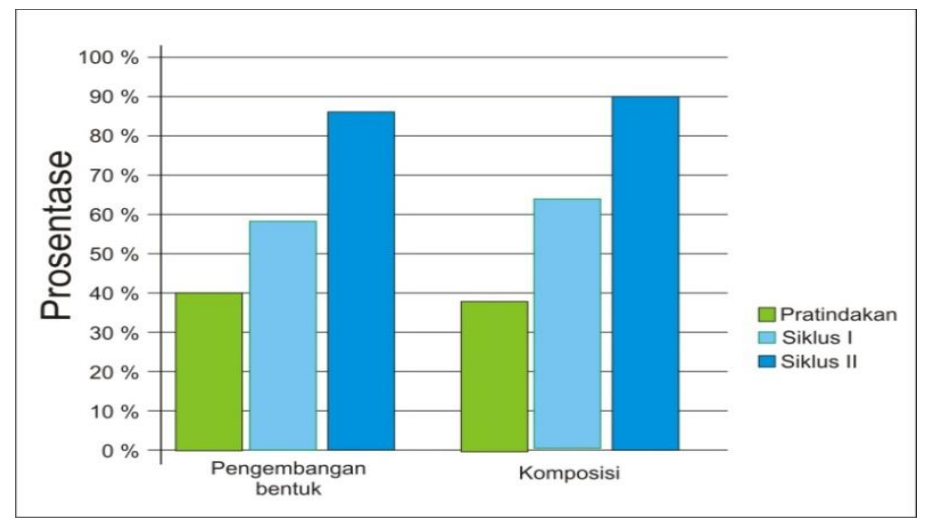

Gambar 2. Peningkatan Kreativitas Siswa dalam Menggambar Ragam Hias

Gambar di atas menunjukkan bahwa kreativitas siswa yang diamati dalam dua aspek pengamatan, yaitu ; 1) pengembangan bentuk pada kondisi awal prosentasenya 40\% menjadi 59\% pada siklus I dan menjadi $86 \%$ pada siklus II. 2) penyusunan komposisi pada pratindakan prosentasenya $39 \%$ menjadi $64 \%$ pada siklus I dan menjadi $90 \%$ pada siklus II. Berikut ini peningkatan ketuntasan belajar siswa dalam menggambar ragam hias dari Kondisi Awal sampai dengan Siklus II.

Tabel 8. Peningkatan Ketuntasan Belajar Siswa dalam Menggambar Ragam Hias

\begin{tabular}{|c|c|c|c|c|c|c|c|c|c|}
\hline \multirow[b]{2}{*}{ No } & \multirow[b]{2}{*}{ Ketuntasan } & \multicolumn{2}{|c|}{ Kondisi Awal } & \multicolumn{2}{|c|}{ Siklus I } & \multicolumn{2}{|c|}{ Siklus II } & \multicolumn{2}{|c|}{ Peningkatan } \\
\hline & & $\begin{array}{c}\text { Jml } \\
\text { Siswa }\end{array}$ & $\%$ & $\begin{array}{c}\text { Jml } \\
\text { Siswa }\end{array}$ & $\%$ & $\begin{array}{c}\text { Jml } \\
\text { Siswa }\end{array}$ & $\%$ & $\begin{array}{c}\text { Jml } \\
\text { Siswa }\end{array}$ & $\%$ \\
\hline 1 & Tuntas & 13 & 40,62 & 23 & 71,87 & 30 & 93,75 & 17 & 53,12 \\
\hline 2 & Tidaktuntas & 19 & 59,37 & 9 & 28,12 & 2 & 6,25 & - & - \\
\hline
\end{tabular}


Berdasarkan peningkatan ketuntasan belajar siswa dalam menggambar ragam hias dari kondisi awal sampai dengan siklus II, dapat diperjelas dengan grafik dibawah ini.

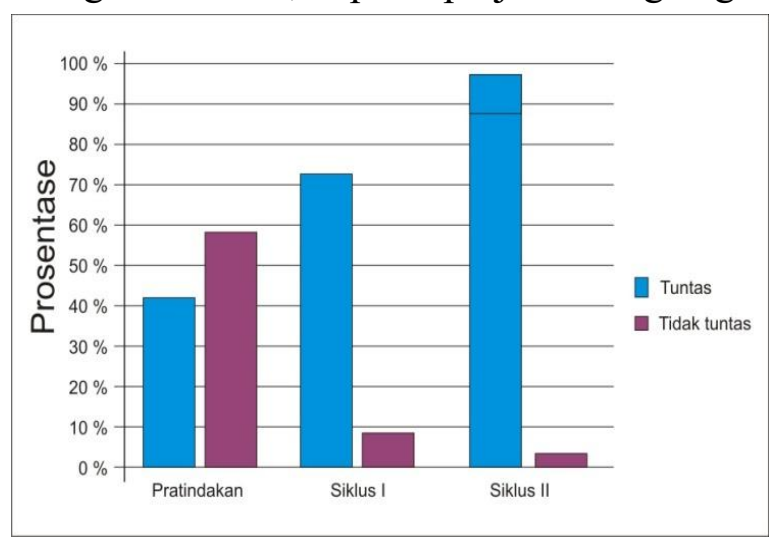

Gambar 4.3 Grafik Peningkatan Ketuntasan Belajar Siswa dalam Menggambar Ragam Hias dari Kondisi Awal sampai dengan Siklus II

Berdasarkan uraian perkembangan hasil tindakan di atas dapat disimpulkan bahwa kreativitas siswa dalam menggambar ragam hias meningkat dengan indikator ketercapaian 1) karya siswa adanya pengembangan bentuk pada kondisi awal prosentasenya $40 \%$ menjadi 59\% pada siklus I dan menjadi $86 \%$ pada siklus II. 2) karya siswa dengan komposisi baik pada pratindakan prosentasenya $39 \%$ menjadi $64 \%$ pada siklus I dan menjadi $90 \%$ pada siklus II.

\section{Simpulan dan Saran}

Berdasarkan hasil penelitian yang telah dilaksanakan, dapat disimpulkan bahwa melalui penerapan metode inkuiri dapat meningkatkan kreativitas siswa kelas VIIC UPTD SMP Negeri 2 Mojolaban Sukoharjo tahun pelajaran 2019/2020. Nilai rata - rata kreativitas siswa meningkat, yaitu dari kondisi awal sebesar 39,5\% menjadi 61,5\% pada Siklus I, dan $88,0 \%$ pada Siklus II.Nilai rata-rata praktek(ketrampilan) menggambar siswa meningkat, yaitu siswa yang tuntas 13 siswa $(40,62 \%)$ pada kondisi awal menjadi 23 siswa $(71,87 \%)$ pada Siklus I, dan 30 siswa $(93,75 \%)$ pada Siklus II.Siswa yang tidak tuntas pada nilai praktek(ketrampilan) menggambar yaitu dari 19 siswa $(59,37 \%)$ pada kondisi awal menjadi 9 siswa $(28,12 \%)$ pada Siklus I, dan 2 siswa $(6,25 \%)$ pada Siklus II.

Berdasarkan simpulan hasil penelitian, peneliti mengajukan saran-saran sebagai berikut : (1) Mengingat penggunaan metode inkuiri dapat meningkatkan kreativitas siswa maka metode ini dapat dijadikan alternative bagi guru dalam kegiatan belajar mengajar; (2) Diperlukannya metode pembelajaran yang bervariasi agar siswa tidak merasa jenuh dan dapat dengan mudah memahami materi yang disampaikan; (3) Siswa perlu dilatih untuk mempersiapkan bahan belajar secara mandiri sehingga siswa tidak mengandalkan sepenuhnya pada guru; (4) Perlunya penelitian dan kajian lebih lanjut untuk menyempurnakan penelitian ini, sehingga dapat lebih bermanfaat bagi peningkatan hasil belajar siswa.

\section{Daftar Rujukan}

Aqib,Z., Jaiyaroh, S., Diniati,E., dan Khotimah, K. (2011). Penelitian Tindakan Kelas. Bandung : CV. Yrama Widya. 
Arikunto, S.,Suhardjono dan Supardi. (2014). Penelitian Tindakan Kelas. Jakarta : Bumi Aksara.

Hamdani. (2011). Strategi Belajar Mengajar. Bandung: CV. Pustaka Setia.

Hamruni. (2012). Strategi Pembelajaran. Sleman Yogyakarta : Insan Madani.

Haryanto, A. dan Waluyo, D. (1988). Pendidikan Seni Rupa untuk SMP. Surabaya: Penerbit CV. al-ihsan.

Munandar,U. (2012). Pengembangan Kreativitas Anak Berbakat. Jakarta: PT. Rineka Cipta.

Nurhadi, Yasin,B., \& Senduk,A.G. (2004). Pembelajaran Kontekstual (Contextual Teaching and Learning/CTL) dan Penerapannya dalam KBK. Malang: Universitas Negeri Malang.

Suwandi, S. (2011). Penelitian Tindakan Kelas (PTK) dan Penulisan Karya Ilmiah. Surakarta : Yuma Pressindo.

Trianto. (2007). Model-model Pembelajaran Inovatif Berorientasi Konstruktivistik: Jakarta: Prestasi Pustaka. 